\title{
FRAMING THE LONG-TERM IN SITU LIABILITY ISSUE FOR GEOLOGIC CARBON STORAGE IN THE UNITED STATES
}

\author{
M.A. DE FIGUEIREDO ${ }^{1, *}$, D.M. REINER ${ }^{2}$ and H.J. HERZOG ${ }^{3}$ \\ ${ }^{1}$ Technology, Management and Policy Program, Massachusetts Institute of Technology, \\ Cambridge, MA, U.S.A. \\ ${ }^{2}$ Judge Institute of Management, University of Cambridge, Cambridge, U.K. \\ ${ }^{3}$ Laboratory for Energy and the Environment, Massachusetts Institute of Technology, \\ Cambridge, MA, U.S.A. \\ (*author for correspondence: Tel: +1-617-253-3770; Fax: +1-617-253-8013; \\ E-mail:defig@mit.edu)
}

(Received 13 November 2003; accepted in final form 22 April 2004)

\begin{abstract}
This paper examines how legal standards of liability may apply to geologic carbon storage. The liability regime governing geologic carbon storage will shape the technology's cost-effectiveness and overall attractiveness. We classify potential sources of liability into operational, in situ, and climate liability. As a first step, we explore in situ liability in the United States. After summarizing legal standards of liability including negligence, breach of implied warranty, strict liability, and product liability, we discuss how liability may be addressed at the level of the federal government, state government, industry, and the firm. Finally, we address the implications of judicial treatment of liability for carbon storage, including the apportionment of liability and the adequacy of current regulations.
\end{abstract}

Keywords: carbon dioxide, geologic, law, liability, regulation, risk, storage

\section{Introduction}

Although technology to capture and store carbon dioxide in geologic formations for climate change mitigation is relatively new, underground injection of carbon dioxide has been used for decades in enhanced oil recovery operations and acid gas injection (Benson 2002). Geologic sinks for carbon dioxide storage include deep saline formations, depleted oil and gas reservoirs, and unmineable coal seams. Together, they have the potential to hold thousands of gigatons of carbon dioxide.

The technical aspects of carbon capture and storage are fairly well documented, and although some questions remain, the path from pilot project to large-scale commercialization seems relatively straightforward (United States Department of Energy 1999). By contrast, the legal liability that private firms will face due to leakage of carbon dioxide from reservoirs has received little attention in the literature, but could significantly affect the viability of carbon storage as a long-term solution to climate change. If liability imposes significant risks or costs, firms may be deterred from engaging in carbon storage. However, legal and regulatory frameworks addressing liability could be developed to decrease firm risk and thereby increase market penetration. 
In this paper, we explore long-term liability for geologic carbon storage in the United States. Our objective is to provide a framework for thinking about the issues. We begin by identifying the potential sources of liability in geologic carbon storage. We then review the liability theories that the United States judiciary has used in analogous cases. Finally, we discuss how legal standards of liability may apply to geologic carbon storage.

The injection of carbon dioxide into geologic reservoirs is an established practice in many states, and the practice is governed by both state and federal jurisdiction. Although liability laws may vary from country to country, there are general principles common to major legal systems (such as administrative rules) and thus our analysis may be applied to addressing liability in other countries.

\section{Sources of Liability}

Before being stored in geologic reservoirs, carbon dioxide would be captured from stationary sources, including industrial processes (e.g., cement), fossil-fueled power plants, and perhaps eventually the wide-scale production of hydrogen fuels from carbon-rich feedstocks. The carbon dioxide would then be compressed, transported and injected into the storage formation. Environmental, health and safety risks associated with these processes are nothing new. Most known risks are associated with well or pipeline failure, primarily regulated by the United States Office of Pipeline Safety (Heinrich et al. 2003). The liability associated with these riskswhat we term operational liability — has been successfully managed in the oil and gas industry, including acid gas injection, enhanced oil recovery, natural gas storage, and carbon dioxide transport (Heinrich et al. 2003).

A second source of liability is associated with leakage from geologic storage reservoirs and its effect on climate change. Assuming that carbon emissions will be controlled under a regulatory regime in the future, there will be a liability associated with leakage. If the effective storage time is thousands of years, that liability would probably be negligible. On the other hand, if the effective storage time is only decades, carbon storage is probably not worth the effort because it is doubtful that the benefits of such a short storage time can justify the extra costs associated with storage. However, if the effective storage time is in between, questions arise as to how to account for this liability. As an example, Herzog et al. (2003) developed a framework that can be used to determine the economic value of what we term climate liability. They conclude that this liability is best addressed as part of a broad climate policy that is enacted to control greenhouse gas emissions.

Once carbon dioxide exits the injection well and enters the geologic formation, its transport and fate are governed by in situ processes. The choice of appropriate sites is the best way to minimize any adverse effects related to carbon dioxide storage. However, there is a potential for leaks of carbon dioxide from the geologic formation to the surface, migration of carbon dioxide within the formation, and 
induced seismicity (Heinrich et al. 2003). Potential sources of liability include public health impacts, and environmental and ecosystem damage.

Carbon dioxide is generally considered a safe, non-toxic gas at low concentrations, and does not directly affect human health. However, carbon dioxide is denser than air and may reaccumulate in low-lying, confined, or poorly ventilated spaces. At high enough concentrations, this can lead to fatal consequences resulting from asphyxiation (Benson 2002). Significant leaks of carbon dioxide could also lead to environmental or ecosystem damage, such as soil acidification or suppression of respiration in the root zone (Benson 2002). It is this third type of liability, which we term in situ liability, that is the focus of our paper.

\section{Legal Standards of Liability}

\subsection{NEGLIGENCE}

Absent specific statutory authority governing liability, most of modern accident law is addressed through negligence claims. Negligence is the failure of a person to exercise reasonable care (American Law Institute: 1965, Restatement, Second, Torts $\S \S 282,283,284)$. Lawsuits often hinge on the interpretation of "reasonable care." Firms which conduct carbon storage activities would be considered professionals. Under negligence law, professionals must exercise the skill and knowledge normally possessed by members of the profession; otherwise they may be found negligent (American Law Institute: 1965, Restatement, Second, Torts § 299A). Industry customs or professional standards may bear on the determination of negligence (American Law Institute: 1965, Restatement, Second, Torts $§ 295 A)$ ). A prima facie case of negligence would need to demonstrate: (1) the individual or firm had a duty to exercise reasonable care; (2) there was a breach of that duty; (3) the plaintiff suffered harm; and (4) the breach of duty caused that harm.

The natural gas transport sector provides an example of negligence law as it is applied. The courts have found that the underground transmission of natural gas is not an abnormally dangerous activity, and that risks can be eliminated by exercising reasonable care and following federal and state regulations (New Meadows v. Washington Water Power 1984). More generally, the degree of care to be exercised is proportional to the dangerous character of the gas and its tendency to escape (Auriemme v. Bridgeport Gas 1958).

\subsection{STRICT LIABILITY}

In an effort to internalize costs with the entity most able to control risk, "strict liability" was established. Under strict liability, a person is held liable for the harm that his or her activity caused, regardless of whether reasonable care was used. Although the ultimate finding of strict liability is made in court, application of strict liability can be imposed by either the courts or the legislature. Strict liability 
is imposed for abnormally dangerous activities. Abnormally dangerous activities are characterized as involving (a) a high degree of risk; (b) the potential for great harm; (c) an inability to eliminate risk by reasonable care; (d) uncommon activities; (e) being inappropriate due to the location where it is carried out; and (f) value to the community that is outweighed by their dangerous attributes (American Law Institute: 1965, Restatement, Second, Torts $\S 520$ ). The list of characteristics is not meant to be exhaustive. The courts ultimately must decide whether the risk created by the activity is so unusual that it warrants payments by a party for any harm caused, regardless of the measures taken to safeguard the activity. Thus, plaintiffs need to provide the court a basis for concluding that an activity was abnormally dangerous, as a matter of law (Dunphy v. Yankee Gas Services 1995). When courts or the legislature define an activity as abnormally dangerous, and therefore governed by strict liability, it has important policy implications. The cost of capital and the cost of insurance coverage may increase. Strict liability may lead firms to purchase insurance to cover potential catastrophic losses or may lead risk-averse firms to curtail activities.

An example of the imposition of strict liability is the case of hazardous waste, governed by the Comprehensive Environmental Response, Compensation and Liability Act or CERCLA (commonly known as Superfund) (42 U.S.C. $§ 9601$ et seq.). Under CERCLA, even if the hazardous substance release problems were unforeseeable, the relevant parties acted in good faith and according to law at the time and exercised reasonable care, or state-of-the-art practices were used at the time the materials were disposed of, a party could still be held liable (United States Environmental Protection Agency 2003a). Moreover, in CERCLA, the statute applies "joint and several liability," meaning that if two or more defendants are held strictly liable, each may be liable for the full damages awarded regardless of fault (American Law Institute: 1965, Restatement, Second, Torts $\S 875$ ). The application of joint and several liability in Superfund cases has led to many different entities, including contractors, transporters, insurers and intermediaries, being held liable (Theurer 2001).

\subsection{IMPLIED WARRANTY}

A third way that firms could be held liable is via a breach of implied warranty. The notion of an "implied warranty of fitness for a particular purpose" is grounded in contract theory. It arises from Article 2 of the Uniform Commercial Code, which applies only to the sale of goods. The sale of a service may give rise to a tort liability based on the concept of breach of implied warranty (Rybarsyk v. R.I. Marketing, Inc. 1988).

Courts will approach the implied warranty differently if the dispute concerns a good or a service. In the case of a good, an "implied warranty of fitness for a particular purpose" is established when (a) a buyer requires goods for a particular purpose and (b) the buyer is relying on the seller's skill or judgment to furnish 
suitable goods (American Law Institute: 2003, Uniform Commercial Code § 2-315). An example of breach of an implied warranty of fitness for a particular purpose would be a person selling a buyer a car that does not run; the car is not fit for the purpose of transportation (Thomas v. Ford Motor Credit Co. 1981). In the case of a service, the Michigan judiciary, for example, has determined that an implied warranty exists when (a) the services rendered involve a potentially hazardous force and (b) the services are "inseverably linked to a tangible product" (Rybarsyk v. R.I. Marketing, Inc. 1988). Examples of breach an implied warranty for a service include an electrical fire caused by a faulty transformer owned by a utility company (Buckeye Union Fire Ins. Co. v. Detroit Edison Co. 1972) and the transfusion of impure blood by a hospital (Hoffman v. Misericordia Hospital of Philadelphia 1970). Some states will only recognize implied warranties for goods, and not for services. Thus the applicability of implied warranties to carbon storage may ultimately come down to whether firms are deemed to be selling carbon dioxide to be stored (a "good") or engaged in a "service" to store carbon.

Another concern is the pathway by which humans might be exposed to high concentrations of carbon dioxide. One possibility is that carbon dioxide could reaccumulate in a confined space. The legal treatment of this risk might then be similar to the case of radon. The buyer of a dwelling assumes that it is habitable when he or she buys it-an implied warranty of habitability. A builder, selleragent, or landlord thus has a responsibility to conduct a reasonably competent and diligent inspection for radon, otherwise he or she can be found liable for breach of warranty (Prussman 1991; Shuko 1986). Note that while it shares many of the same characteristics as an implied warranty of fitness, an implied warranty of habitability is distinct and narrower in construction.

\subsection{PRoduct LIABILITY}

Finally, the courts could impose product liability although it would likely be harder to apply to the case of carbon storage than other legal standards of liability. Product liability claims depend on the jurisdiction of the court and may be based on theories of negligence, strict liability or breach of implied warranty. There are three areas where product liability may be applied. The first would be damages arising from "manufacturing defects," where the finished product (the stored carbon in our case) does not conform to the design specifications (Restatement, Third, Torts: Products Liability $\S 2(a))$. The second would be "design defects," where the finished product is manufactured according to specifications, but the specifications themselves are flawed and result in an unreasonably dangerous product (American Law Institute: 1998, Restatement, Third, Torts: Products Liability $\S 2$ (b)). In such cases, the judiciary weighs the benefits of a design against the risks of harm (American Law Institute: 1998, Restatement, Third, Torts: Products Liability $§ 2$, Comment (a)). Any "risk-utility balancing" would need to be conducted in the context of reasonably foreseeable risks, in light of the knowledge of risks and risk-avoidance 
techniques - the judiciary would not impose liability related to product design on risks that are not foreseeable (American Law Institute: 1998, Restatement, Third, Torts: Products Liability § 2, Comment (a)). A third area would be the failure to warn of a possible danger, where a seller could be held liable for not warning the buyer against dangers of product misuse (American Law Institute: 1998, Restatement, Third, Torts: Products Liability $\S 2(\mathrm{c})$ ). Examples of well-known product liability cases include asbestos, inadequate drug labels, and exploding automobile gas tanks (MDU Resources Group v. W.R. Grace \& Co. 1994; Benedi v. McNeil-P.P.C., Inc. 1995; Grimshaw v. Ford Motor Co. 1981).

\section{Addressing Liability}

Given this potentially complicated situation for liability, what can be done to address the situation of carbon capture and storage? Liability could be dealt with on four levels: the federal government, state government, industry, and the firm. These are nonexclusive; approaches will probably take place on multiple levels, for example combining federal statutes with firm-level strategies.

The federal government may be able to take on some of the burdens that would otherwise be borne by industry. An example of this is the Price-Anderson Act of 1957, which establishes a framework for payments to the public in the case of a nuclear accident (42 U.S.C. $\S 2210$ et seq.). Under this act, nuclear plants are required to take on private insurance amounting to $\$ 200$ million per plant. In addition, all nuclear plant operators contribute to an industry trust fund of $\$ 9.3$ billion. The federal government assumes any liability above the combined $\$ 9.5$ billion paid in by industry. The Act has been renewed three times since 1957. The 1988 reauthorization explicitly extended coverage to government contractors, required the Department of Energy to establish and enforce nuclear safety rules, and created a federal cause of action (or public liability) for claims related to a nuclear incident (Guttman 2002). In recent debates, opponents of reauthorization have portrayed the Act as a subsidy to the nuclear industry, so that although the Act expired most recently in August 2002, it was temporarily extended through the end of 2003 as a rider to the Omnibus Appropriations Bill, Fiscal Year 2003.

A "liability cap" may be a double-edged sword for carbon storage. On one hand, it would provide industry with some certainty as to the financial liability associated with any leakage. On the other hand, a liability cap could be detrimental to carbon storage from a public perception standpoint. Liability caps are quite rare and are generally reserved for areas of real catastrophic risk. They are also necessary for situations where no insurance company would be willing to bear the full damages of disaster. For example, in addition to nuclear accidents, Congress has authorized a $\$ 100$ billion cap on terrorist-related losses by the Terrorism Risk Insurance Act (15 U.S.C. $\S 6701$ et seq.). It is likely that liability caps could stigmatize carbon storage by associating its risks with those of high-level nuclear waste and terrorism. 
A second means of addressing liability would be for the states to bear liability, as in the case of low-level radioactive waste. Low-level radioactive waste includes machine parts from nuclear reactors, clothing worn by workers in radioactive facilities, medical waste, and waste from university research laboratories. It is governed by the Low Level Radioactive Waste Policy Act, as amended in 1985, which dictates that states are responsible for the disposal of low-level radioactive waste generated within their borders (42 U.S.C. $\S 2021$ b et seq.). The Act allows states to enter into compacts to control access to disposal facilities. The unintended effect of the Act has been that no new low level radioactive waste facilities have been built, largely because no state regulatory agency will approve a disposal facility within its borders (Murray et al. 2003). The example of low-level radioactive waste shows that liability regimes may discourage storage. It also raises questions of the efficacy of turning liability over to the states.

Industry as a whole may be able to bear liability for carbon storage. In the case of the Price Anderson Act, industry is required to undertake a joint insurance pool in which all plants must participate. In the event of a nuclear accident where the plant's $\$ 200$ million insurance pool is used up, the joint insurance pool would be triggered, whereby each nuclear reactor must pay up to $\$ 88$ million to cover damages. This insurance pool is only feasible because all operators are required to participate in it (Deutch et al. 2003).

Finally, there is the case of firms addressing potential liability on their own. EPA administers the Underground Injection Control Program (UIC) under the authority of the Safe Drinking Water Act of 1974. UIC regulates the underground injection of waste in order to prevent the contamination of water resources. EPA's regulatory framework for underground injection will shape the regulatory environment for geologic carbon storage and may inform assessments of the risks (Wilson et al. 2003). As part of UIC, owners of Class I injection wells (wells that inject hazardous and nonhazardous waste below the lowermost formation containing an underground source of water) must demonstrate financial responsibility in case of accidents. Acceptable indicators include surety bonds (guarantee by a surety company that a specified obligation will be fulfilled), letters of credit (guarantee that a set amount of money will be available to a specified company under certain conditions), trust funds (repositories of money set aside for a specific purpose), and financial statements (audited information from a company's income statement and balance sheet demonstrating sufficient resources for specific obligations) (United States Environmental Protection Agency 1990). A recent United States General Accounting Office report, however, has noted that these requirements may not assure that adequate resources are available in the event that a firm declares bankruptcy or ceases operations (United States General Accounting Office 2003). According to the report, the financial assurance requirements Class II oil and gas deep injection wells (similar to aspects of the Class I requirements) are being reviewed internally by EPA because of concerns that they may not be adequate. There are also uncertainties about the adequacy of Resource Conservation 
and Recovery Act (RCRA) financial assurance requirements, upon which the UIC financial requirements are based. EPA has admitted that the risk associated with financial assurance may be higher than initially estimated and sufficient funds may not be available when they are needed (United States Environmental Protection Agency 2003b).

Moreover, assuming the liability for carbon storage is adjudged low enough, some insurance companies may be willing to bear the risk. Insurance companies will gravitate to situations where risk categories can be pooled, or where the likelihood of accidents can be predicted. The availability of insurance will depend on assessments of the risk of carbon dioxide leakage from a geologic reservoir. Although research assessing the general environmental, health and safety risks of geologic carbon storage has already started (e.g., Benson 2002), risk assessments will be needed on a site-by-site basis. Whether a firm can even be insurable for long-term liability will depend on the predictability of risk and the extent of potential damages.

\section{What Does This Mean for Carbon Storage?}

The courts' treatment of liability in analogous cases has some important implications for geologic carbon storage. The first is the apportionment of liability. As shown in the hazardous waste example of strict liability, joint and several liability (where each defendant can be held liable for full damages regardless of fault) is one way that liability could be apportioned. This leads to questions as to the extent of liability. In the case of hazardous waste, potentially responsible parties include the current owner or operator of the facility, prior owners or operators at time of disposal, generators of hazardous waste, transporters of hazardous waste, and even entities that arranged for transportation. In a world where there is no specific statutory authority governing carbon storage, the negligence standard would require apportionment of liability that will depend on state tort law statutes and judicial precedent. Apportionment of liability could be aimed at reducing accidents (placing burden on those best able to change behavior) or based on reducing the cost of accidents (placing burden on those best able to pay) (Calabresi 1970). Liability will also depend on mineral property rights, which vary from state to state. A firm seeking to store carbon dioxide in a specific geologic reservoir would need to know who owns the rights to the reservoir, and what those specific rights entail. There may be analogous experience in the underground natural gas storage industry, where companies inject and store natural gas in underground reservoirs. The industry has found that entities with potential property rights include the land surface owner, the mineral interest owner, the royalty owner, and the reversionary interest owner (interest in a reservoir that becomes effective at a specified time in the future) (McGaha 1986).

Another important issue is the adequacy of current regulations. For example, carbon dioxide has not been classified as a hazardous waste in the United States. 
As a result, liability from carbon dioxide emissions has not been an important issue for private firms. Any reclassification-for example, in a new climate regimewould make liability a more visible issue. Thus, if foreign countries classify carbon dioxide as a hazardous waste, this may bear on how the United States government and United States firms treat liability. In addition, liability could be subject not only to domestic regulations, but also intergovernmental standards. In the area of ocean carbon storage, international treaties have been unclear on the legality and liability of carbon dioxide injection; geologic storage could face similar hurdles. There may be implications for geologic storage if carbon dioxide is classified a hazardous waste under an international regime related to ocean storage (Lenstra et al. 2003).

Consideration of long-term liability is a key element in assessing the viability of geologic carbon storage. The way in which liability is addressed may have a significant impact on costs and indirectly on public perceptions of geologic storage. Liability itself is not a new topic; indeed operational liability of carbon dioxide injection is handled routinely in the oil and gas industries as a part of doing business. The critical question is how the judiciary, legislatures, and regulatory authorities will treat geologic storage once it enters as a potentially important mitigation measure in the more controversial area of climate change policy. Whether liability for geologic carbon storage will be treated more like the historic treatment of natural gas which has imposed relatively low costs on operators or more like hazardous waste which has been much more burdensome to participants (and much more politicized) is uncertain. The answer will depend in part on the results of current research assessing the risks of this technology, the first projects that attempt to store carbon on a large scale explicitly for the purposes of reducing emissions of carbon dioxide to the atmosphere, the reaction of the public and interest groups to those risks and efforts, and actuarial and financial analyses of liability.

\section{Acknowledgements}

We gratefully acknowledge the financial support of EPRI and the MIT Carbon Sequestration Initiative.

\section{References}

American Law Institute: 1965, Restatement of the Law, Torts $2 d$, St. Paul, American Law Institute Publishers.

American Law Institute: 1998, Restatement of the Law, Torts 3d-Product Liability, St. Paul, American Law Institute Publishers.

American Law Institute: 2003, Uniform Commercial Code, St. Paul, American Law Institute Publishers. 
Auriemme v. Bridgeport Gas Company, 144 A.2d 701 (Conn.Super. 1958).

Benedi v. McNeil-P.P.C., Inc., 66 F.3d 1378 (4th Cir. 1995).

Benson, S.: 2002, Lessons Learned from Natural and Industrial Analogues for Storage of Carbon Dioxide in Deep Geological Formations, Report No. LBNL-51170, Berkeley, E.O. Lawrence Berkeley National Laboratories.

Buckeye Union Fire Ins. Co. v. Detroit Edison Co., 38 Mich. App. 325 (1972).

Calabresi, G.: 1970, The Costs of Accidents: A Legal and Economic Analysis, New Haven, Yale University Press.

Deutch, J. and Moniz, E.J. (co-chairs): 2003, The Future of Nuclear Power: An Interdisciplinary MIT Study, Cambridge, Massachusetts Institute of Technology.

Dunphy v. Yankee Gas Services Company, 1995 WL 631006 (Conn.Super. 1995).

Guttman, D.: 2002, 'Price-Anderson act reauthorization: Due diligence is in order', Environmental Law Reporter News and Analysis 32, 10594-10602.

Grimshaw v. Ford Motor Company, 119 Cal. App. 3d 757 (4th Dist. 1981).

Heinrich, J.J., Herzog, H.J. and Reiner, D.M.: 2003, 'Environmental Assessment of Geologic Storage of $\mathrm{CO}_{2}$ ', The Second Annual Conference on Carbon Sequestration, Alexandria, VA, United States Department of Energy.

Herzog, J., Caldeira, K. and Reilly, J.: 2003, 'An issue of permanence: Assessing the effectiveness of ocean carbon sequestration', Climatic Change 59(3), 293-310.

Hoffman v. Misericordia Hospital of Philadelphia, 439 Pa. 501 (1970).

Lenstra, W.J. and van Engelenburg, B.C.W.: 2003, 'Legal and Policy Aspects: Impact on the Development of $\mathrm{CO}_{2}$ Storage', Prepared for Workshop on Carbon Capture and Storage, Regina, Intergovernmental Panel on Climate Change.

McGaha, F.: 1986, 'Underground gas storage: Opposing rights and interests', Louisiana Law Review 46, 871-890.

MDU Resources Group v. W.R. Grace \& Co., 14 F.3d 1274 (8th Cir. 1994).

Murray, P. and Spence, D.: 2003, 'Fair weather federalism and America's waste disposal crisis', Harvard Environmental Law Review 27, 71-103.

New Meadows Holding Company v. Washington Water Power Company, 102 Wash.2d 495 (1984).

Prussman, J.: 1991, 'The Radon riddle: Landlord liability for a natural hazard', Boston College Environmental Affairs Law Review 18, 715-750.

Rybarsyk v. R.I. Marketing, Inc., 1988 U.S. Dist. LEXIS 18063 (1981).

Shuko, C.M.: 1986, 'Radon gas: Contractor liability for an indoor health hazard', American Journal of Law and Medicine 12, 241-272.

Theurer, K.M.: 2001, 'Sharing the burden: Allocating the risk of CERCLA clean-up costs', The Environmental Lawyer 7(3), 477-554.

Thomas v. Ford Motor Credit Company, 48 Md. App. 617 (1981).

United States Department of Energy: 1999, Carbon Sequestration Research and Development, Report DOE/SC/FE-1, Washington, DC, United States Department of Energy.

United States Environmental Protection Agency: 1990, Federal Financial Responsibility Demonstrations for Owners and Operators of Class II Oil- and Gas-Related Injection Wells, Report EPA 570/9-90-003, Washington, DC, United States Environmental Protection Agency.

United States Environmental Protection Agency: 2003a, Superfund Liability, Available online at: http://www.epa.gov/Compliance/cleanup/superfund/find/liability.html [last updated June 30, 2003].

United States Environmental Protection Agency: 2003b, RCRA Financial Assurance for Closure and Post-Closure, Report No. 2001-P-007. 
United States General Accounting Office: 2003, Deep Injection Wells: EPA Needs to Involve Communities Earlier and Ensure that Financial Assurance Requirements Are Adequate, Report to the Honorable Lynn C. Woolsey, House of Representatives, Report GAO-03-761, Washington, DC, United States General Accounting Office.

Wilson, E.J., Johnson, T.L. and Keith, D.W.: 2003, Regulating the ultimate sink: Managing the risks of geologic $\mathrm{CO}_{2}$ Sstorage, Environmental Science and Technology 37, 3476-3483. 